\title{
Construction of a Scale for Evaluating Turkish Learning Students' Attitude towards Turkish Language (Tashkent Case Study) ${ }^{*}$
}

\begin{tabular}{ccc}
\hline Article Type & Received Date & Accepted Date \\
Research & 22.05 .2018 & 06.10 .2018 \\
\hline
\end{tabular}

\author{
Khabib Akhmadjonov $^{* *}$
}

\author{
Mustafa Altun ${ }^{* * * *}$
}

\begin{abstract}
"Attitude" in foreign language teaching is a concept that defines the overall beliefs and behaviour of students towards the language they learn. Students' eagerness for learning the language increases in cases where the attitude is positive, whereas this process is hindered in cases where the attitude is negative. Our study aimed at constructing a scale for evaluation of foreign students' attitudes towards Turkish language education, since the literature strived for a scale that evaluated attitudes towards Turkish Education as a foreign language. This scale, comprising of 73 items was applied to 206 students in Uzbekistan that were learning Turkish, and corresponding validity and reliability studies were conducted. As a result of relevant analyses, it was determined that the scale consisted of 61 items belonging to 5 distinct factors, i.e; listening, speaking, writing, reading and comprehension and attitude\&motivation. Calculation of Cronbach's Alpha reliability coefficients having a valueover 0.70 suggested that the scales were reliable. Moreover, having the fit indices obtained by confirmatory factor analyses within the acceptable ranges proved that the constructional validities of scales were attained. Results of EFA-CFA and item analyses revealed that the scale was sufficiently applicable for students learning Turkish as a foreign language.
\end{abstract}

Keywords: Foreign language learning, motivation, attitude, reliability, validity.

\footnotetext{
* This study was derived from the research part of the doctoral thesis called "Effects of Turkish Success of Attitudes Related to Turkish Students Who Turkish Learners in Uzbekistan Universities"

** PhD Student, Sakarya University, Institute of Educational Science, Department of Turkish and Social Sciences Education, Turkish Education Program Sakarya, Turkey. E-mail: habib.ahmadjonov.85@mail.ru

${ }^{* * *}$ Corresponding Author: Assoc. Prof. Dr., Sakarya University, Faculty of Education, Department of Turkish and Social Sciences Education, Turkish Education Program, Sakarya, Turkey. E-mail: maltun @ sakarya.edu.tr
} 


\title{
Türkçe Öğrenen Öğrencilerin Türkçeye İlişkin Tutumlarını Belirlemeye Yönelik Ölçek Geliştirme Çalışması (Taşkent Örneği)*
}

\begin{tabular}{ccc}
\hline Makale Türü & Başvuru Tarihi & Kabul Tarihi \\
Araştırma & 22.05 .2018 & 06.10 .2018 \\
\hline
\end{tabular}

Khabib Akhmadjonov**

\author{
Mustafa Altun ${ }^{* * *}$
}

\begin{abstract}
$\ddot{O} z$
Yabanc1 dil öğretiminde "tutum” öğrencilerin öğrenim gördüğü dile karşı sahip oldukları tüm düşünce ve davranışlardır. Öğrencilerin yabancı dile karşı olan tutumları olumlu veya olumsuz olabilir. Yabancı dil öğrenen öğrencilerin dile olan tutumu olumluysa öğrenme isteği artar ve dil öğrenme sürecini kolaylaştırır, tutum olumsuz ise öğrenmeyi engeller. Türkçe öğrenmeye yönelik tutumların belirlenebileceği ölçeğin alanyazında eksikliği duyulduğundan çalışmamızda yabancı öğrencilerinin Türkçe öğrenimine yönelik tutum ölçeğinin geliştirilmesi amaçlanmıştır. 73 madde olarak hazırlanan ölçme aracı Özbekistan'daki 206 Türkçe öğrenen öğrenciye uygulanıp geçerlik ve güvenirlik analizleri yapılmıştır. Yapılan analizler sonucunda, ölçekte toplam 61 madde ortaya çıkmış ve bu maddelerin 5 farklı boyutta (dinleme, konuşma, yazma, okuma ve anlama, tutum ve motivasyon) toplandığı bulunmuştur. Cronbach Alfa güvenirlik katsayıların .70 değerinin üzerinde hesaplanması, ölçeklerin güvenilir olduğunu göstermektedir. Ayrıca yapılan doğrulayıcı faktör analizi sonucunda hesaplanan uyum indekslerinin kabul edilebilir aralıklarda olması da ölçeklerin yapı geçerliliklerinin sağlandığını ortaya koymaktadır. AFA-DFA ve madde analizlerinin sonuçları, ölçeğin Türkçe öğrenen öğrencilere uygulanabilir düzeyde olduğunu göstermektedir.
\end{abstract}

Anahtar Sözcükler: Yabancı dil öğrenme, motivasyon, tutum, güvenirlik, geçerlilik.

\footnotetext{
* Bu makale, “Özbekistan'daki Üniversitelerde Türkçe Öğrenen Öğrencilerin Türkçeye İlişkin Tutumlarının Türkçe Başarısına Etkisi (Taşkent Örneği)" başlıklı doktora tezinden üretilmiştir.

** Doktora Öğrencisi, Sakarya Üniversitesi Eğitim Bilimleri Enstitüsü, Türkçe ve Sosyal Bilimler Eğitimi Anabilim Dalı, Türkçe Eğitimi Bilim Dalı, Sakarya, Türkiye. E-posta: habib.ahmadjonov.85@mail.ru

**** Sorumlu Yazar: Doç. Dr., Sakarya Üniversitesi, Eğitim Fakültesi, Türkçe ve Sosyal Bilimler Eğitimi Bölümü, Türkçe Eğitimi Anabilim Dalı, Sakarya, Türkiye. E-posta: maltun@ sakarya.edu.tr
} 


\section{Introduction}

Being a transitional phase into a new age, the $21^{\text {st }}$ century demands improvement, modernization and qualitative efficiency of learning processes of human beings and our society. Development of educational methods that focus on the psychological status of students as a prerequisite for the effectiveness of the educational system and that cater for students' real needs by enhancing their creative skills are thus becoming prominent in higher educational institutions.

As a result of educational reforms undertaken after the independence of Uzbekistan and cooperation in the educational field between Uzbekistan and Turkey, positive attitudes toward the Turkish language -especially for Turkish spoken in Turkey- is rapidly being enhanced among Uzbekistan youth. Establishment of Turkish companies in Uzbekistan and watching Turkish series on television triggered an increase in the number of younger people who desired to learn Turkish and this number keeps on ever increasing. Hence, the responsibility of teachers as qualified experts for teaching Turkish as a foreign language should also be extended. Results of various theoretical and experimental research demonstrated that the prerequisite for the effectiveness of Turkish language education was the students' attitude towards the language and that it was directly related to the enhancement of motivation. Application of novel interactive educational methods for language education does not always yield to differentiated educational principles. Detachment from the language environment creates additional challenges regarding the motivation for language learning. A communicational, personalized approach that is based on cognitive and personality principles should be developed for Turkish language teaching. First of all, the language education should be provided based on students' field of interest, needs and motivations.

Language is the most important tool that human beings use to express their thoughts and emotions. The language that human beings use to convey their pasts to the future passes down numerous elements regarding the concepts differing from culture to arts, from existence to faith, and from history to present; beyond any doubt containing the cultural elements of societies (Kumsar and Kaplankıran, 2016).

Mete (2015), stated that the purpose of education for any language was the improvement of students' language skills. The main objective for Turkish language teaching is also the improvement of students' language skills. Language skills are based on comprehension and explanation. Comprehension comprises of reading and listening skills, whereas explanation involves speaking and writing skills. The person who provides the student with language skills can be said to be an efficient teacher.

According to Çakır (2015), a person who wants to learn a foreign language has to strive for speaking, writing, listening and comprehending, and reading in that language. Students' language skills will not nourish without proper motivation and attitudes of such students toward language would be negative. Dörnyei and Csizer (1998), state that the motivation is responsible for success in foreign language learning and students with inadequate motivation or that have different skills would not achieve high results and targets even if their education is provided by efficient teachers.

According to Gardner (1985), motivation has a major role in foreign language teaching. Motivation involves positive attitudes towards foreign language learning. And is based on factors that have the ability to satisfy students. Motivation nourishes in case the student strives for foreign language education and hence the corresponding attitude towards the language would be positive. This means that the students' objectives and desires regarding foreign language education would be clearly and expressly defined. Therefore, the effect of motivation with respect to planning and practising teaching should not be ignored (Mutlu, 2012).

Hall (2011) suggested that the motivation was the key factor for realizing a specific activity. He further advocates that it would even be hard to imagine learning a language without motivation. Furthermore, teachers express that the success or disappointment in language learning generally resulted due to either the presence or the absence of motivation and attitude. 
Attitude is generally termed to be a tendency for giving positive or negative reactions. A student learning a foreign language also has negative or positive attitudes towards the language $\mathrm{s} / \mathrm{he}$ is learning (Genç et al., 2016) Attitude is the overall summation of thoughts or behaviour they retain with respect to a certain subject. For instance a positive attitude towards the foreign language is demonstrated through the students' confidence and contentedness while talking in the foreign language, his/her eagerness to be in places where that language is spoken and his/her encouragement to people around him/her for the need of foreign language education (Özge Dagoğlu, 2004).

"Attitude" is the overall summation of thoughts or behaviour they retain with respect to a certain subject. Attitudes towards foreign language education might either be positive or negative. For instance, a positive attitude towards the foreign language is demonstrated through the students' confidence and contentedness while talking in the foreign language, his/her eagerness to be in places where that language is spoken and his/her encouragement to people around him/her for the need of foreign language education (Özge Dağoğlu, 2004).

Considering attitudes, Eagly and Chaiken (1993) suggest that an attitude is a psychological tendency. One can perform a task either willingly or unwillingly. Once there exists a need, the motivation nourishes in human beings, leading them to strive for their objectives.

According to Fishbein ve Ajzen (1975) attitude is a process. Negative or positive attitudes towards an event developafter a certain process. Nobody is born into this world innately loving or hating certain matters. Human beings are neutral to everything at first, and attitudes start to develop as time goes by.

Attitudes are vital in foreign language teaching. The attitude of the student towards a foreign language can be either positive or negative. A student with a positive attitude towards foreign language learning also has a strong intrinsic motivation for studying that language, which makes him/her more willing to learn that language and in turn making him/her reach their objectives more easily. A student with a negative attitude towards foreign language learning will have low levels of willingness to study, thus the process for achieving their objectives would be harder and more challenging. Hence, foreign language teachers should not oversee students' attitudes towards the language (Ref. Karatay, Kartallıŏlu, 2016).

Research regarding foreign students learning Turkish is not common and mostly focused on concepts of self-efficacy and attitude. Within the scope of research where self-efficacy of students learning Turkish as a foreign language with respect to comprehension skills, Tulumcu (2014) constructed a valid and reliable measurement tool that can measure levels of self-efficacy for listening and reading skills. Whereas, Okonkwo Ali (2001) in his research where he evaluated the relationship between Kazakh and Kirghiz students' attitudes towards the Turkish language, and their success in learning Turkish, he constructed a scale for measuring the effect of Kazakh and Kirghiz students attitudes towards the Turkish language in their Turkish learning success.

Nekzad (2016) used a (45) item 5-point-Likert-Scale that was constructed by Alzwari, PourMohammadi ve Abidin (2012) and adapted to Turkish by researchers for evaluating attitudes of Afghani students towards the Turkish language that are learning Turkish as a foreign language.

\section{The Aim of the Research}

"Attitude" in foreign language teaching is a concept that defines the overall beliefs and behaviour of students towards the language they learn. Students' attitude towards the foreign language might have a positive as well as a negative form. Students' eagerness for learning the language increases in cases where the attitude is positive, which in turn paves the way for foreign language learning process or prevents this process in cases where the attitude is negative. Positive attitudes and motivation are interrelated concepts since both behavioursare based on needs. The objective of this study is the construction of a valid and reliable assessment tool for determining the degree of attitude towards the Turkish language for students that learn Turkish at universities in Uzbekistan. 


\section{Importance of the Study}

Being the first study for determining the degree of attitude towards Turkish language for students that learn Turkish at universities in Uzbekistan, as well as the effectiveness of listening, speaking, writing, reading and understanding skills in language teaching, and the importance of attitude and motivation in language learning, our research is of importance in the field.

\section{Method}

\section{Population sample}

A total of 206 students that learn Turkish at Uzbekistan universities were included with respect to scale development process. The scale was constructed by performing statistical analyses on the data obtained from the population sample.

\section{Construction of the Scale}

An item pool with respect to attitudes towards Turkish language learning was generated as the first stage of constructing the Scale for Evaluation of Turkish Learning Students' Attitudes Towards the Turkish Language. A total of 73 items were collected in the item pool. A 5-point-Likert-Scale was utilized for expression of agreement degree to the scale items. These degrees were stated respectively as: "Absolutely disagree (1), Disagree (2), Neutral (3), Agree (4), and Strongly agree (5)".

Social scientists, academicians that specialize in Turkish language field views were taken primarily for face and construct validity and assessment and evaluation with respect to validity studies. Scale items were adjusted according to the views and critics received and consequently applied to the population sample. The scale for applied to the population sample for construct validity and reliability studies. Explanatory factor analysis was performed primarily for the construct validity. For the determination of items to be included in the scale by explanatory factor analysis, attention was paid for having eigenvalues of 1 ,factor loadings of 30 , the location of the item only in on factor andhaving a difference of 10 where the item is located on two factors. In order for determining the distinct factors, factors having eigenvalues above 1 and the rate of explained variance were considered (Büyüköztürk, 2002).

Model fit of item-factor relationship obtained by explanatory factor analysis was tested by confirmatory factor analysis. Pearson correlation coefficients were utilized for determining the relationship between the scale factors. Item analysis techniques based on the differences between means of two groups and differences within groups, and based on items' total correlation was utilized for the analyses of items to be included in the scale. Internal consistency and split test methods were utilized for predicting the reliability of the scale. Cronbach's alpha internal consistency coefficient was calculated for predicting reliability by internal consistency method. SPSS 20 package program was used for data analysis, whereas Lisrel 8.7 was used for confirmatory factor analysis.

\section{Findings and Discussion}

This section contains the findings obtained by validity and reliability studies based on the results attained from the application of 73-item-scale to 206 students learning Turkish. Descriptive analyzes, exploratory and confirmatory factor analysis, item analysis, factor reliability analysis and determination of factor relationships were carried out during the construction of scale. Findings obtained with respect to validity and reliability studies were depicted in figures and interpreted as such through these stages.

\section{Validity Study}

Exploratory Factor Analysis and Confirmatory Factor Analysis were utilized for analyzing the scale's factor structure.

\section{Exploratory Factor Analysis (EFA)}

EFA results for 5 subscales and 73 items related to attitudes of Turkish learning students were evaluated. Results of Kaiser-Meyer-Olkin (KMO) test that was firstly conducted for determining the 
adequacy of sample size for analysis and results of Barlett's sphericity test conducted for determining the suitability are provided in Table 1.

Table 1

KMO and Barlett Test Results for Scales

\begin{tabular}{lcc}
\hline Scales & KMO & Barlett's Test of Sphericity \\
\hline Listening Scale & .864 & $1633.957^{*}$ \\
Speaking Scale & .923 & $2172.485 *$ \\
Writing Scale & .892 & $1162.110^{*}$ \\
Reading and Comprehension Scale & .901 & $1065.733^{*}$ \\
Attitude and Motivation Scale & .846 & $9452.063 *$ \\
\hline
\end{tabular}

$* \mathrm{p}<.01$

Having a KMO rate over 60 signifies the "adequacy" of sample sizefor factor analysis (Brownlow, 2004, Pett, Lackey \& Sullivan, 2003). Furthermore, significant values for chi-square were determined to inspect the results of Bartlett's test of sphericity. $(\mathrm{p}<.01)$. Taking these results into consideration, it was accepted that data could be factorized (Pett, Lackey \& Sullivan, 2003; Child, 2006; Hutcheson \& Sofroniou, 1999).

Results of analyses revealed that the 5 scales were consisting of a single factor just as is in their original form. Factor loadings for "Listening Scale",was observed to vary between .385 and.843 (4 items having factor loading below .30 wereeliminated from the scale). Moreover, the scale was observed to explained a variance of $52.83 \%$. Factor loadings for "Speaking Scale".was observed to vary between .548 and .862 . Moreover, the scale was observed to explain a $60.15 \%$ variance (3 items having factor loadings below .30 were eliminated from the scale). Factor loadings for the "Writing Scale"wasobserved to vary between .548and .802. Moreover, the scale was observed to explain a $54.152 \%$ variance ( 1 item having a factor loading below . 30 was eliminated from the scale). Factor loadings for "Reading and Comprehension Scale"were observed to vary between .418 and .842 . Moreover, the scale was observed to explain a variance of 57.65\%. It was observed that the factor loadings of "Attitude and Motivation Scale" varied between .401 and .681. Moreover, the scale was observed to explain a variance of $45.82 \%$.

\section{Confirmatory Factor Analysis (CFA)}

DFA was performed for determining the fitness rate of the scale's factor structure and collected data, and corresponding fitness values are provided in Tablo 2 below. An acceptable to good fitness was generally observed while inspecting the fit indices.

\section{Table 2}

DFA Fit Indices

\begin{tabular}{lc}
\hline Scales & Fit Indices \\
\hline \multirow{2}{*}{ Listening Scale } & $\chi 2 / \mathrm{sd}=2.28 ; \mathrm{RMSEA}=.052, \mathrm{GFI}=.91$, \\
\multirow{3}{*}{ Speaking Scale } & $\mathrm{AGFI}=.90 \mathrm{CFI}=.95$, and NFI $=.93$ \\
\cline { 2 - 2 } Writing Scale & $\chi 2 / \mathrm{sd}=1.89 ; \mathrm{RMSEA}=.064, \mathrm{GFI}=.90$, \\
& $\mathrm{AGFI}=.90 \mathrm{CFI}=.93$, and $\mathrm{NFI}=.95$ \\
\cline { 2 - 2 } Reading and Comprehension Scale & $\chi 2 / \mathrm{sd}=2.56 ; \mathrm{RMSEA}=.065, \mathrm{GFI}=.93$, \\
& $\mathrm{AGFI}=.90 \mathrm{CFI}=.95$, and NFI $=.93$ \\
\cline { 2 - 2 } Attitude and Motivation Scale & $\mathrm{\chi} 2 / \mathrm{sd}=1.67 ; \mathrm{RMSEA}=.053 \mathrm{GFI}=.92$, \\
\cline { 2 - 2 } & $\chi \mathrm{AGFI}=.91, \mathrm{CFI}=.96$, and NFI $=.92$ \\
\hline
\end{tabular}




\section{Reliability}

\section{Item analysis}

item total correlation

Item Total Correlations explains the relationship between scores obtained from test items and the total test score. Positive and higher values of item-total correlations indicate that the items are sampling similar behaviour, which in turn indicates high internal consistency (Büyüköztürk, 2008).

It was observed that the Item Total Correlation of the scale itemswas observed to vary between .31 and .80 . It can be suggested that each of the scales was discriminating individuals well as a result of these analyses results. since items with an item total correlation value of 30 and moreis said to discriminate individuals having the measured attribute form the ones that do not have the related attribute to a good extent (Benoit, 2008).

Obtaining significantly different results from a comparison of average item scores by independent sample t-tests performed after forming two groups as the lower $27 \%$ and upper $27 \%$ groups regarding the scores attained from scales might be taken as an indication of the test's internal consistency. t-test results for comparison of scale's upper and lower $27 \%$ percent groups are provided in Table 4. Having significant values for all the items on each scale $(\mathrm{p}<.01)$ can be said to indicate the tendency of scale items to measure the attribute they specify.

Table 3

t-test Results for Upper $27 \%$ percent and Lower $27 \%$ Groups

\begin{tabular}{lcc}
\hline Scales & Min. & Max. \\
\hline Listening Scale & -10.45 & 3.172 \\
Speaking Scale & -7.235 &.- .843 \\
Writing Scale & -6.157 & .390 \\
Reading and Comprehension Scale & -8.487 & -1.306 \\
Attitude and Motivation Scale & -8.395 &.- .144 \\
\hline
\end{tabular}

Cronbach's alpha and split half test correlations

Internal consistencies of constructed 5 subscales were investigated using Cronbach's alpha coefficient and reliability was tested using the split-half reliability test. Cronbach's Alpha coefficient values and split-half correlation values are provided in Table 4.

\section{Table 4}

The Cronbach's Alpha Coefficient and the Two Half-Test Correlation Values of the Scales

\begin{tabular}{lccc}
\hline Scales & $\begin{array}{c}\text { Number } \\
\text { of Items }\end{array}$ & $\begin{array}{c}\text { Cronbach's } \\
\text { Alfa }\end{array}$ & R \\
\hline Listening Scale & 12 & .87 & .83 \\
Speaking Scale & 14 & .91 & .86 \\
Writing Scale & 11 & .88 & .83 \\
Reading and Comprehension Scale & 9 & .90 & .89 \\
Attitude and Motivation Scale & 15 & .81 & .87 \\
\hline
\end{tabular}

Having internal consistency coefficients greater than .70 is generally deemed to be sufficient for the reliability of the scale (Liu, 2003). Therefore, having internal consistency coefficients greater than 0.70 for each scale and results obtained by inspecting Spearman-Brownsplit-half test indicate sufficient reliability of the scale.

\section{Conclusions}

Because Turkish and Uzbek are members of Turkish language family, they are similar in terms of sound, form, word, sentence and meaning structure. This similarity leads to problems in the education of Turkish. It may not be easy to learn this new language, which is not completely similar to 
some Uzbek students. The rules of sound harmony of Uzbek language are different from Turkish. This can cause problems in listening, speaking, writing and reading skills. This situation is a great task for Turkish teachers as a foreign language. The opening of Turkish companies in Uzbekistan, watching the Turkish series, listening to Turkish music has increased the demand of young people especially to learn Turkish. This demand can be met by qualified teachers, quality textbooks and materials. But that is not enough. The students should have positive attitudes and motivations about Turkish. At this point, it is important for the students to determine the listening, speaking, writing, reading, understanding attitude and motivation levels. The determined levels will make teaching strategies and environments more effective.

Validity and reliability studies of Evaluation of foreign students' attitudes towards Turkish language education were conducted throughout this research. The scale comprised of 5 distinct subscales (listening, speaking, writing, reading and comprehension, attitude and motivation). Calculation of Cronbach's Alpha reliability coefficients having a valueover 0.70 (in the range of .81.91 ) and having split half test correlation values between. 83 and.89 demonstrated that the scales were reliable. Item total correlation values of scale itemswere observed to vary between .31 and .80 . It can be suggested that each of the scales was discriminating individuals well as a result of these analyses results. Significantly different results for scale items were obtained from comparisons of average item scores by independent sample t-tests performed after forming two groups as the lower $27 \%$ and upper $27 \%$ groups regarding the scores attained from scales $(\mathrm{p}<.(\mathrm{p}<.01)$. High scores obtained in each of the scales indicated that the individual's attitudes towards Turkish education were high.Results of EFACFA and item analyses can be interpreted as the scale was fit for application to Turkish learning students. Reliability and validity can be applied to different sample groups and new researches can be done.

\section{References}

Büyüköztürk, Ş. (2002). Sosyal bilimler için veri analizi el kitabı: İstatistik, araştırma deseni, SPSS uygulamalarl ve yorum [Handbook of data analysis for social sciences: Statistics, research design, SPSS applications and interpretation]. Ankara: Pegem Academy Publishing.

Brownlow, C. (2004). SPSS explained. London: Routledge.

Child, D. (2006). The essentials of factor analysis. London: Continuum International Publishing Group.

Çakır, G. (2015). Yabancı dilde konuşma becerisinin geliştirilmesinde öğretmen adaylarının görüşleri [Opinions of the teacher candidates on the development of speaking skills in foreign language]. International Journal of Social Science, 40, 193-203. https://www.jasstudies.com/Makaleler/1824652509_14Yrd.\%20Do\%c3\%a7.\%20Dr.\%20G\%c3\%bclcan\%20\%c3\%87AKIR.pdf Access: 10.04.2018

Dörnyei, Z. \& Csizer, K. (1998) Ten commandments for motivating language learners: Results of an empirical study. Language Teaching Research, 2(3), 205-229. http://journals.sagepub.com/doi/10.1177/136216889800200303 Access: 10.04.2018

Eagly, A. H. \& Chaiken, S. (1993). The Psychology of attitudes. Fort worth: Harcourt Brace Jovanovich.

Fishbein, M. \& Ajzen, I. (1975). Belief, attitude, intention, and behavior: An introduction to theory and research. reading. MA: Addison-Wesley.

Gardner, R. C. (1985). Social psychology and second language learning: The role of attitude and motivation. London: Edward Arnold.

Hall, G. (2011). Exploring English language teaching language in action. London: Routledge.

Hutcheson, G. D. \& Sofroniou, N. (1999). The multivariate social scientist: Introductory statistics using generalized linear models. Thousand Oaks, CA: Sage.

Jöreskog, K.G. \& Sörbom, D. (1993). LISREL 8: Structural equation modeling with the SIMPLIS command language. Hillsdale, NJ: Lawrence Erlbaum Associates Publishers.

Karatay, H. ve Kartallıglu, N. (2016). Yabancı dil olarak Türkçe öğrenme tutumu ile dil becerileri edimi arasındaki ilişki [The relation between the attitude of learning Turkish as foreign language 
and acqusition of language skills]. Journal of AIBU Social Sciences Institute. 16(4), 203-213. http://sbedergi.ibu.edu.tr/index.php/sbedergi/article/view/1324 Access: 15.04.2018.

Kumsar, E. ve Kaplankıran, İ. (2016). Kazakların Türkiye Türkçesi öğreniminde yaptıkları yanlışlıklar ve bu yanlışlıkların düzeltilmesine yönelik öneriler [The mistakes that the Kazakh have done in learning Turkey Turkish and suggestions for aiming at the correction of them]. Journal of Diyalektolog. 12, 81-103.

http://www.diyalektolog.com/DergiTamDetay.aspx?ID=105\&Detay=Ozet Access: 01.05.2018

Mete, F. (2015). Türkçe öğretmenliği bölümünde yazma eğitimi dersi: Bilme ve uygulama karşılaştırması [Writing course in Turkish education department: Comparison to knowledge and practice]. Journal of Ana Dili Ĕgitimi. 3(2), 81-91.

http://www.anadiliegitimi.com/download/article-file/14892 Access: 15.04.2018.

Mutlu, S. (2012). Bilimsel süreç becerileri odakl fen ve teknoloji ĕgitiminin ilköğretim ögrrencilerinin bilimsel süreç becerileri, motivasyon, tutum ve başarl üzerine etkileri [The assessment of the attitude toward the target language of Afghan studens learning Turkish as a foreign language]. (Unpublished Master dissertation). Trakya University, Institute of Science.

Nekzad, M. (2016). Türkçeyi yabancı dil olarak ögrrenen Afganistan uyruklu öğrencilerin Türkçeye karşl tutumlartnin incelenmesi [The assessment of the attiude toward the target language of Afghan studens learning Turkish as a foreign language]. (Unpublished Master dissertation). Dokuz Eylul University, Institute of Education Sciences, Izmir, Turkey.

Oyarkılıçgil Ateş, A. (2001). Kazak ve Kırgız öğrencilerin Türkçeye karşı tutumlarının Türkçe ögrrenim bașarllariyla ilişkisi [The relation between Kazakh and Kirghiz students attitudes towards turkish and their success in learning turkish language]. (Unpublished $\mathrm{PhD}$ dissertation). Ankara University, Institute of Social Sciences, Ankara, Turkey.

Özge Daglıoglu, F. (2004). Üniversite hazırlı sınıfi öğrencilerinin yabancı dil derslerine olan tutumların arttırlmasi ve program düzenlenmesi [An analysis of ways of improving positive attitudes towards foreign language learning amongst university prep school students and suggesstions on curriculum development]. (Unpublished $\mathrm{PhD}$ dissertation), Yildiz Technic University, Institute of Social Sciences, Istanbul, Turkey.

Pett, M. A., Lackey, N. R., \& Sullivan, J. J. (2003). Making sense of factor analysis: The use of factor analysis for instrument development in health care research. Thousand Oaks, CA: Sage.

Tulumcu, F. M. (2014). Yabancı dil olarak Türkçe ögrenenlerin anlama becerilerine yönelik öz yeterlikleri [Self-efficacy for comprehension skills of learners of Turkish as a foreign language]. (Unpublished Master dissertation), Sakarya University, Institute of Education Sciences, Sakarya, Turkey. 